\title{
Release of plasma atrial natriuretic peptide after volume expansion is not related to pituitary-adrenal axis diurnal variation in normal subjects
}

\section{L.L.K. Elias ${ }^{1}$, \\ J. Antunes-Rodrigues ${ }^{2}$ and A.C. Moreira ${ }^{1}$}

\author{
Departamentos de ${ }^{1}$ Clínica Médica e ${ }^{2}$ Fisiologia \\ Faculdade de Medicina de Ribeirão Preto, \\ Universidade de São Paulo, \\ 14049-900 Ribeirão Preto, SP, Brasil
}

\section{Correspondence}

A.C. Moreira

Departamento de Clínica Médica

Faculdade de Medicina de

Ribeirão Preto, USP

14049-900 Ribeirão Preto, SP

Brasil

Fax: 55 (016) 633-1144

Research supported by FAPESP and Hospital das Clínicas de

Ribeirão Preto (HCFMRP-FAEPA).

Received February 28, 1996

Accepted February 14, 1997

\begin{abstract}
The existence of a circadian rhythm of atrial natriuretic peptide (ANP) in humans is controversial. We studied the plasma ANP response to isotonic blood volume expansion in the morning and in the afternoon and its relationship with adrenocorticotropic hormone (ACTH)-cortisol diurnal variation in seven normal subjects. Basal plasma ANP level was similar in the morning $(19.6 \pm 2.4 \mathrm{pg} / \mathrm{ml})$ and in the afternoon $(21.8 \pm 4.8 \mathrm{pg} / \mathrm{ml})$. The ANP peak obtained with saline infusion $(0.9 \% \mathrm{NaCl}, 12 \mathrm{ml} / \mathrm{kg})$ in the morning $(49.4 \pm 8 \mathrm{pg} / \mathrm{ml}) \mathrm{did}$ not differ from that obtained in the afternoon $(60.3 \pm 10.1 \mathrm{pg} / \mathrm{ml})$. There was no correlation between the individual mean cortisol and ACTH levels and the ANP peak obtained with saline infusion. These data indicate no diurnal variation in plasma ANP secretion induced by blood volume expansion and no relationship between plasma ANP peak and ACTH-cortisol diurnal variation.
\end{abstract}

Key words

- ANP

- Diurnal variation

- ACTH

- Cortisol
Atrial natriuretic peptide (ANP) is a 28amino acid peptide hormone released by cardiac myocytes due to an increase in atrial pressure induced by blood volume expansion. The hormone plays an important role in the regulation of body fluid homeostasis and blood pressure (1). ANP was described originally in the cardiac atria and was later detected in the brain with prominent concentration in the hypothalamus (2). The presence of ANP within the central nervous system suggests that it may act as a neuromediator. ANP immunoreactive neurons were described in the paraventricular nucleus, where corticotropin-releasing hormone $(\mathrm{CRH})$ and vasopressin-containing cell bodies are also localized, with high concentrations of ANPcontaining nerve fibers and terminals extending into the external zone of the median eminence which constitutes the final common pathway for signals to reach the pituitary gland $(3,4)$.

These anatomical data support the view that ANP may be involved in the regulation of the hypothalamic-pituitary-adrenal axis acting as an inhibitor of this system (5-7). However, other reports have not confirmed this inhibitory effect of ANP on adrenocorti- 
cotropic hormone $(\mathrm{ACTH})$ secretion $(8,9)$. In addition, the existence of a circadian rhythm in plasma ANP concentration in humans is still a matter of controversy (10-12). There are no detailed reports on the daily variation in plasma ANP response to saline in humans.

The purpose of the present study was to determine whether there is a daily variation in the plasma ANP response to isotonic saline infusion and its relationship with the diurnal variation of the pituitary-adrenal axis in normal subjects.

Seven normal subjects, four females and three males aged 26 to 34 years, taking no medication, were studied on two occasions, once in the morning and once in the afternoon separated by at least 15 days. Informed consent to participate in the study was obtained from the subjects. The protocol was approved by the University Hospital Ethics Committee.

In the morning, after an overnight fast the subject rested for $1 \mathrm{~h}$ and maintained the supine position during the study. Isotonic saline $(0.9 \% \mathrm{NaCl}, 12 \mathrm{ml} / \mathrm{kg})$ was infused over a 1 -h period starting at 8:30 $\mathrm{h}$. In the afternoon, the volunteers had a light lunch at 12:00 $\mathrm{h}$ and were not allowed to eat or drink anything thereafter. After the subject rested for $1 \mathrm{~h}$, saline infusion was started at 17:00 h. Venous blood was withdrawn immediately before saline infusion and at 15-min intervals for $2 \mathrm{~h}$. Plasma cortisol, ACTH and ANP were measured at all sampling times. ACTH was determined by radioimmunoassay (RIA) after extraction from plasma using silicic acid (13). Plasma cortisol was determined by RIA after ethanol extraction (14). ANP was measured by RIA after plasma extraction according to the method of Gutkowska et al. (15). Two $\mathrm{ml}$ of plasma was acidified by adding $2 \mathrm{ml} 0.1 \%$ trifluoroacetic acid (TFA) and centrifuged and then adsorbed onto an activated octadecylsilane cartridge (SEP-COLUMN, Peninsula Laboratories, Belmont, CA). ANP was eluted from each cartridge with $3 \mathrm{ml}$ acetonitrile/ $0.1 \%$ TFA solution (60:40). The recovery of human ANP added to plasma was $68.5 \%$. The eluates were lyophilized and reconstituted in assay buffer. The ANP antiserum was provided by Dr. Jolanta Gutkowska. Synthetic human ANP (1-28) was radiolabelled with $\mathrm{Na}{ }^{125} \mathrm{I}$ by the lactoperoxidase method and purified by reverse-phase high-pressure liquid chromatography on a $\mathrm{C}_{18} \mu$ Bondapak column. Antibody-bound and free ANP were separated using goat anti-rabbit antiserum. Plasma sodium was measured by flame photometry and hematocrit was determined by a standard method. The assay sensitivity was $1.1 \mu \mathrm{g} / \mathrm{dl}$ for cortisol, $15.0 \mathrm{pg} / \mathrm{ml}$ for ACTH and $1.0 \mathrm{pg} / \mathrm{ml}$ for ANP. All assays had intraassay coefficients of variation $(\mathrm{CVs})$ of 4.3$5 \%$ and interassay CVs of $10-17 \%$. The samples from each subject were analyzed in duplicate in the same assay.

For statistical analysis, values below the detection limit of each assay were considered to be equal to half of the minimum detectable dose. Data are reported as mean \pm SEM and were analyzed by the Wilcoxon matched pairs test and Spearman rank correlation with the level of significance set at $\mathrm{P}<0.05$.

Baseline serum sodium concentration did not change after saline infusion either in the morning $(140 \pm 1.9 v s 141 \pm 1.8 \mathrm{mEq} / \mathrm{l})$ or in the afternoon $(142 \pm 1.1$ vs $142 \pm 1.6 \mathrm{mEq} / \mathrm{l})$. The hematocrit was significantly decreased $(\mathrm{P}<0.03)$ during saline infusion in the morning $(39.6 \pm 1.2 \%$ vs $37.7 \pm 1.4 \%)$ and in the afternoon $(38.0 \pm 1.4$ vs $36.3 \pm 1.2 \%)$.

There was no difference between basal plasma ANP obtained in the morning (19.6 \pm $2.4 \mathrm{pg} / \mathrm{ml})$ and in the afternoon $(21.8 \pm 4.8$ $\mathrm{pg} / \mathrm{ml}$ ). Isotonic saline infusion elicited an increase in ANP secretion $(\mathrm{P}<0.05)$. The highest plasma ANP value obtained for each subject in the morning $(49.4 \pm 8 \mathrm{pg} / \mathrm{ml}) \mathrm{did}$ not differ from that obtained in the afternoon $(60.3 \pm 10.1 \mathrm{pg} / \mathrm{ml})$ (Figure 1). The time course of plasma ANP, cortisol and ACTH 
during isotonic saline infusion obtained in the morning and in the afternoon is shown in Figure 2. Plasma cortisol and ACTH from all seven subjects were increased in the morning when compared to the levels obtained in the afternoon with mean values of $7.0 \pm 0.7$ vs $3.0 \pm 0.4 \mu \mathrm{g} / \mathrm{dl}(\mathrm{P}<0.02)$ and $26.0 \pm 2.9 v s$ $15.4 \pm 1.2 \mathrm{pg} / \mathrm{ml}(\mathrm{P}<0.05)$, respectively. The mean plasma ANP level obtained during saline infusion was similar in the morning $(33.4 \pm 3.8 \mathrm{pg} / \mathrm{ml})$ and in the afternoon $(33.7$ $\pm 7.2 \mathrm{pg} / \mathrm{ml}$ ). There was no correlation between the individual mean cortisol and ACTH levels and the ANP peak obtained with saline infusion.

The existence of a circadian rhythm of ANP in humans is still somewhat controversial. The present study analyzed the diurnal variation of saline-stimulated ANP secretion, and its putative relationship with $\mathrm{ACTH}-$ cortisol secretion.

Our results demonstrate that there is no difference between morning and afternoon either in basal plasma ANP secretion or in its response to isotonic blood volume expansion. The circadian rhythm of ANP levels in humans has not been well established. Follenius et al. (12) showed no intrinsic daily variation in plasma ANP concentration in normal subjects who had remained in the supine position for $24 \mathrm{~h}$. However, other authors have documented plasma ANP peak values at 4:00 $\mathrm{h}(10,11)$ and at midday in normal active subjects (16). These different results may reflect different study conditions, and the present data obtained from two timings of the samples might not represent 24-h diurnal variation. In addition, the ANP secretion in our subjects occurred without change in serum sodium, in agreement with the finding that ANP secretion in man is mainly regulated by plasma volume status (17).

Recently, we demonstrated that the circadian variations in plasma ANP and corticosterone are similar in rats fed ad libitum or on a restricted feeding schedule (18). The disagreement between our previous results of ANP daily variation in rats and the present result in humans suggests a possible physiological difference between species.

Our data showed higher plasma cortisol and ACTH levels in the morning than in the afternoon characterizing the well-known
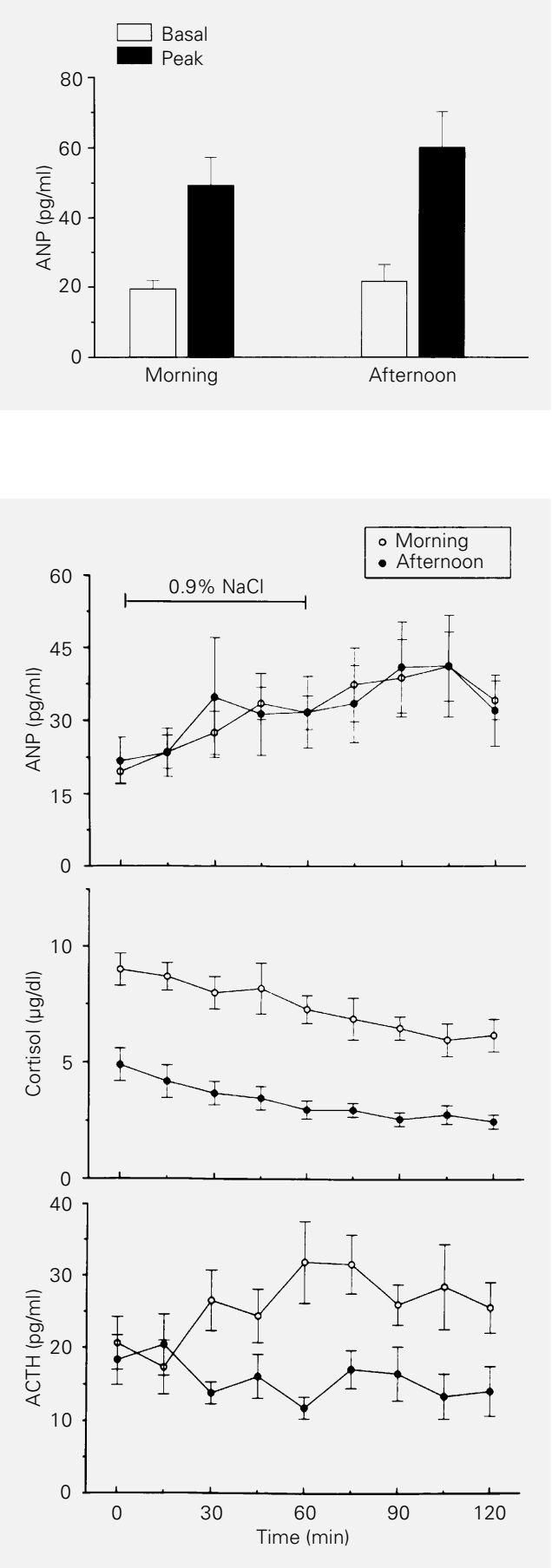

Figure 1 - Basal and peak plasma ANP obtained during isotonic saline infusion in the morning and in the afternoon. Data are reported as mean \pm SEM for 7 normal subjects.

Figure 2 - Plasma concentrations of ANP, cortisol and ACTH during isotonic saline infusion in the morning and in the afternoon. Data are reported as mean \pm SEM for 7 normal subjects. 
normal pituitary-adrenal diurnal variation. Our results indicate that there is no relationship between daily pituitary-adrenal axis variation and saline-induced ANP secretion in humans, suggesting no interplay between ANP and ACTH-cortisol diurnal variation. Originally we analyzed the interaction of ANP with physiological ACTH-cortisol variation on the basis of endogenous ANP released by blood volume expansion. Our results agree with those reported by $\mathrm{Ur}$ et al. (19) who used exogenous ANP at physiological doses which did not modify basal and CRH-stimulated ACTH or cortisol levels in normal human subjects. Also in rats, ANP does not affect basal or secretagogueinduced ACTH secretion (9). However, we cannot rule out a central role for ANP as a modulator of pituitary secretion, since ANP concentration is two to four times greater in hypophyseal portal blood than in peripheral blood (20).

In conclusion, we showed that there is no diurnal change in plasma ANP levels in response to isotonic saline infusion and that there is no correlation between plasma ANP level and pituitary-adrenal diurnal variation.

\section{Acknowledgments}

The authors thank Miss Adriana Rossi and Miss Lucimara Bueno for technical assistance. Reagents for ACTH RIA were supplied by the National Hormone and Pituitary Program, NIDDK (USA) and Dr. Toshihiro Suda (Tokyo Women's Medical College, Tokyo, Japan). The ANP antiserum was kindly provided by Dr. Jolanta Gutkowska (Centre de Recherche Hôtel-Dieu de Montréal, Canada).

\section{References}

1. Needleman P \& Greenwald JE (1986). Atriopeptin: a cardiac hormone intimately involved in fluid, electrolyte, and bloodpressure homeostasis. New England Journal of Medicine, 314: 828-834

2. Standaert DG, Needleman $P$ \& Saper $C B$ (1986). Organization of atriopeptin-like immunoreactive neurons in the central nervous system of the rat. Journal of Comparative Neurology, 253: 315-341.

3. Zamir N, Skofitsch G, Eskay RL \& Jacobowitz DM (1986). Distribution of immunoreactive atrial natriuretic peptides in the central nervous system of the rat. Brain Research, 365: 105-111.

4. Palkovits M, Eskay RL \& Antoni FA (1987). Atrial natriuretic peptide in the median eminence is of paraventricular nucleus origin. Neuroendocrinology, 46: 542-544.

5. Ibanez-Santos J, Tsagarakis S, Rees LH, Besser GM \& Grossman A (1990). Atrial natriuretic peptides inhibit the release of corticotrophin-releasing factor-41 from the rat hypothalamus in vitro. Journal of Endocrinology, 126: 223-228.
6. Dayanithi G \& Antoni FA (1990). Atriopeptins are potent inhibitors of ACTH secretion by rat anterior pituitary cells in vitro: involvement of the atrial natriuretic receptor domain of membrane-bound guanylyl cyclase. Journal of Endocrinology, 125: 39-44.

7. Fink G, Dow RC, Casley D, Johnston $\mathrm{Cl}$, Lim AT, Copolov DL, Bennie J, Carrol S \& Dick H (1992). Atrial natriuretic peptide (ANP) is a physiological inhibitor of adrenocorticotrophin (ACTH) secretion in the rat. Journal of Physiology, 446: 441 (Abstract).

8. Horvath J, Ertl T \& Schally AV (1986). Effect of atrial natriuretic peptide on gonadotropin release in superfused rat pituitary cells. Proceedings of the National Academy of Sciences, USA, 83: 34443446.

9. Hashimoto K, Hattori T, Suemaru S, Sugawara M, Takao T, Kageyama J \& Ota Z (1987). Atrial natriuretic peptide does not affect corticotropin-releasing factor-, arginine vasopressin and angiotensin IIinduced adrenocorticotropic hormone release in vivo or in vitro. Regulatory Peptides, 17: 53-60.
10. Donckier J, Anderson JV, Yeo T \& Bloom SR (1986). Diurnal rhythm in the plasma concentration of atrial natriuretic peptide. New England Journal of Medicine, 315: 710-711.

11. Portaluppi F, Bagni B, Uberti E, Montanari L, Cavallini R, Trasforini G, Margutti A, Ferlini M, Zanella M \& Parti M (1990). Circadian rhythms of atrial natriuretic peptide, renin, aldosterone, cortisol, blood pressure and heart rate in normal and hypertensive subjects. Journal of Hypertension, 8: 85-95.

12. Follenius $M$, Brandenberger $G$ \& Saini $J$ (1992). Lack of diurnal rhythm in plasma atrial natriuretic peptide. Life Sciences, 51: 143-149.

13. Moreira AC, Barizon EA \& Silva JR (1987) Standardization of a radioimmunoassay for plasma ACTH. Arquivos Brasileiros de Endocrinologia e Metabologia, 31: 19-22.

14. Vieira JGH (1977). Radioimmunoassay of serum cortisol. Master's thesis, Escola Paulista de Medicina, São Paulo.

15. Gutkowska J, Horky K, Thibault G, Januszewicz $P$, Cantin M \& Genest J (1984). Atrial natriuretic factor is a circulating hormone. Biochemical and Biophysical Research Communications, 30: 315323. 
16. Richards AM, Tonolo G, Fraser R, Morton JJ, Leckie BJ, Ball SG \& Robertson JIS (1987). Diurnal changes in plasma atrial natriuretic peptide concentrations. Clinical Science, 73: 489-495.

17. Kamoi K, Sato F, Arai O, Ishibashi M \& Yamaji T (1988). Effects of plasma volume and osmolality on secretion of atrial natriuretic peptide and vasopressin in man. Acta Endocrinologica, 118: 51-58.
18. Oliveira MHA, Antunes-Rodrigues J, Leal AMO, Elias LLK \& Moreira AC (1993). Circadian variation of plasma natriuretic peptide and corticosterone in rats with continuous or restricted access to food. Life Sciences, 53: 1795-1801.

19. Ur E, Faria M, Tsagarakis S, Anderson JV, Besser GM \& Grossman A (1991). Atrial natriuretic peptide in physiological doses does not inhibit the ACTH or cortisol response to corticotrophin-releasing hormone-41 in normal human subjects. Journal of Endocrinology, 131: 163-167.
20. Lim AT, Sheward WJ, Copolov D, Windmill D \& Fink G (1990). Atrial natriuretic factor is released into hypophysial portal blood: direct evidence that atrial natriuretic factor may be a neurohormone involved in hypothalamic pituitary control. Journal of Neuroendocrinology, 2: 16-18. 